PEDAGOGIA : Jurnal IImu Pendidikan

\title{
MENDULANG IMBAS SALAH KAPRAH, SALAH GARAP
}

\author{
Mujahidil Mustaqim, Sherly Sere \\ Universitas Pendidikan Indonesia \\ mujahidil.mustaqim@student.upi.edu
}

\begin{abstract}
This article reviews that in fact the most fundamental and crucial aspect of education is the quality of teachers. So efforts to improve teacher quality must be a top priority over the interests of others. The common perception circulating that the curriculum is everything but the teacher as the translator of the curriculum substance does not get a meaningful governor. As a result, a curriculum that is designed in such a way is estimated not to be able to fully carry out its functions. Misguided, which then leads to wrong work. This article is described using literature studies and documentation. There are three main things that are studied, namely, First, the data that explains the achievement of the teacher professionalism program that encompasses academic qualifications, teacher certification, teacher professionalism programs and teacher competency tests are fairly low which then has the potential for the effectiveness of curriculum implementation in the field. Secondly, some problems that arise due to the lack of teacher professionalism is the implementation of the objectives, content, methods and evaluation of the curriculum not as expected. Third, the flow of education improvement should start from improving teacher quality. In addition, in the formulation of the curriculum should be at the same time formulated what teacher competencies required in the curriculum design. Then, the guidelines are prepared for teachers in the form of steps that can be passed by the teacher in implementing the curriculum. As a result, not ignorant of efforts to improve the quality of teachers so that students can touch the essence of the curriculum that has been designed.
\end{abstract}

Keywords: Professionalization and Competency of Teachers, Curriculum, Teacher

\begin{abstract}
Abstrak
Artikel ini mengulas bahwa sebenarnya aspek yang paling fundamental dan krusial dalam pendidikan adalah mutu guru. Maka upaya peningkatan mutu guru harus menjadi prioritas utama di atas kepentingan yang lainnya. Persepsi yang lazim beredar bahwa kurikulum adalah segalagalanya namun guru sebagai penerjemah substansi kurikulum tidak mendapat gubris yang berarti. Alhasil, kurikulum yang didesain sedemikian rupa ditaksir tak mampu sepenuhnya menjalankan fungsinya. Salah kaprah yang kemudian berbuntut pada salah garap. Artikel ini didesripsikan menggunakan studi literatur dan dokumentasi. Ada tiga hal pokok yang dikaji yaitu Pertama, data yang menerangkan tentang ketercapaian program profesionalisme guru diantaranya kualifikasi akademik, sertifikasi guru, program profesionalisme guru dan uji kompetensi guru terbilang rendah yang kemudian berpotensi terhadap efektifitas implementasi kurikulum di lapangan. Kedua, beberapa persoalan yang timbul akibat kadar pencapaian profesionalisasi guru yang minim adalah penerapan tujuan, isi, metode dan evaluasi kurikulum tak berjalan sebagaimana yang diharapkan. Ketiga, alur pembenahan pendidikan hendaknya dimulai dari peningkatan mutu guru. Selain itu, pada saat perumusan kurikulum hendaknya pada waktu yang bersamaan juga dirumuskan kompetensi guru apa saja yang disyaratkan dalam desain kurikulum. Kemudian
\end{abstract}


disusun pedoman bagi guru berupa langkah-langkah yang dapat dilalui guru dalam menerapkan kurikulum. Alhasil, peserta didik dapat mereguh esensi kurikulum yang telah dirancang tersebut.

Kata Kunci: Profesional dan Kompetensi Guru, Kurikulum, Guru

\section{A. PENDAhULUAN}

Menakar persoalan pendidikan yang dihadapi bangsa ini tidak bertengger pada satu dimensi saja, akan tetapi jika mau jujur maka terlalu banyak persoalan pendidikan yang membelenggu. Akibatnya, pendidikan bangsa ini dinilai lamban mengalami kemajuan. Hal ini dinilai lumrah karena pendidikan pada negara berkembang mempunyai tendensi susah untuk menerima hal-hal yang baru (Sindhunata, 2001, hlm. 1). Dengan kata lain, adanya sikap konservatif meskipun hal-hal baru yang dimaksud adalah nyatanyata baik dan sudah seharusnya. Diantara persoalan pendidikan yang kerap mengundang kontemplasi yang runyam adalah kurikulum dan mutu guru. Dua hal pokok ini merupakan tumpuan di garda depan pendidikan nasional.

Tanpa kurikulum yang sustainable dan guru yang profesional, maka pendidikan tidak akan benar-benar menjadi milik peserta didik. Kurikulum (Idi, 2007, hlm. 46) yang dalam arti dipahami sebagai sejumlah mata pelajaran adalah objek yang akan guru ajarkan kepada peserta didik. Agar dapat tersampaikan dengan maksimal, maka dibutuhkan guru yang berkompeten. Pada Forum Konres Dunia ke lima organisasi Guru Sedunia disebutkan ada beberapa isi krusial tentang urgensi mutu guru dalam kelangsungan pendidikan, yaitu Pertama, diperlukan ekstrakapasitas untuk menyediakan guru yang profesional sejati dalam jumlah yang cukup, sehingga siswa yang memasuki bangku sekolah tidak terjebak pada ngarai kesiaan akibat layanan pendidikan dan pembelajaran yang buruk. Kedua, meningkatkan kesejahteraan dan status guru serta tenaga kependidikan lainnya (Danim, 2011, hlm. 1-2).
Namun realita yang terjadi adalah peningkatan kesejahteraan guru tidak memberikan dampak yang signifikan terhadap pelayanan pendidikan. Kondisi ini kembali menjadi viral di media sosial dengan hadirnya pernyataan Menteri Keuangan Republik Indonesia. Sebagaimana yang dilansir oleh salah satu media nasional Tempo, Sri Mulyani menyatakan bahwa sertifikasi guru saat ini tidak dijadikan sebagai gambaran guru yang betul-betul profesional dan tidak menggambarkan guru yang bertanggung jawab terhadap kualitas mengajar. Sekarang sering sertifikasi itu tidak mencerminkan apa-apa. Dia mungkin hanya prosedural saja untuk bisa mendapat tunjangan (Hendartyo, 2018). Hal tersebut mempunyai arti bahwa upaya untuk meningkatkan mutu guru tidak cukup dengan meningkatkan kesejahteraan guru semata. Namun, harus ada upaya tentang bagaimana guru benar-benar komitmen meningkatkan kualitas diri secara mandiri dan ikhlas.

Pada sisi lain, penulis juga melihat kondisi ini adalah sebuah dilema. Pemerintah mengadakan sertifikasi sebagai penunjang kesejahteraan guru agar mutu guru dapat meningkat. Pada saat tunjangan guru sudah berjalan melalui sertifikasi, mutu guru yang sudah disertifikasi masih kerap dipertanyakan karena dinilai belum memberi dampak yang massif terhadap pelayanan pendidikan. Pada sisi sebaliknya, jika tunjangan kesejahteraan guru tidak dianggarkan, maka banyak pihak yang mengatakan ini adalah penyebab utama mutu guru rendah. Dengan demikian, pemberian tunjangan kesejateraan guru untuk meningkatkan mutu guru dan kualitas pendidikan bener-bener harus dikawal dan 
bukan satu-satunya faktor penghambat mutu guru rendah.

Pada dasarnya, persoalan mutu guru mestilah menjadi topik yang paling laris dibicarakan dan dikaji daripada berbicara pergantian kurikulum itu sendiri. Karena peneliti secara pribadi melihat tidak masalah apa dan bagaimana kurikulum itu berganti sesuai dengan kebutuhan zaman yang terus berbeda, akan tetapi yang menjadi persoalan dari tahun ke tahun adalah kesiapan mutu guru dalam setiap pergantian kurikulum tersebut. Pemerintah hendaknya lebih concern terhadap pembinaan dan pelatihan yang harus diberikan kepada guru setiap kurikulum diganti. Bukan hanya sekedar concern desain kurikulum yang dibuat. Mestilah ada pelatihan guru yang masif dan berkala. Karena apalah arti bagusnya kurikulum yang didesain sesuai tuntutan perbedaan kebutuhan zaman jika mutu guru sebagai penerjemah kurikulum tersebut diabaikan. Sehingga esensi kurikulum yang didesain tersebut tidak dapat diterima oleh peserta didik secara maksimal karena terkendala oleh mutu penerjemah kurikulum kepada peserta didik di lapangan.

Pemerintah seharusnya lebih sibuk dan banyak meluangkan waktu memikirkan bagaimana meningkatkan mutu guru daripada kurikulum itu sendiri. Karena jika mutu guru sudah bagus, maka bagaimanapun kurikulum yang akan dirancang dan diimplementasikan tidak menjadi masalah lagi bagu guru sebagai implementator. Karena sudah siap secara mental dan akademik untuk mengajarkan seperti apapun kurikulum yang dirancang pemerintah. Mutu guru yang di dalamnya memuat sejumlah kompetensi kompetensi yang harus dimiliki jika kompetensi tersebut belum memadai ditambah kinerja guru rendah, maka Huda (2017) mengemukakan hal ini mengakibatkan rendahnya prilaku belajar siswa, lebih jauhnya tingkat prestasi belajar siswa akan rendah.
Berdasarkan urgensi dari besarnya kebutuhan peran guru terutama sebagai sosok penerjemah sekaligus implementator desain kurikulum pada tingkat mikro tentu harus disertai upaya pembentukan profesionalisme guru. Karena tanpa ini, kandungan yang terdapat dalam desain kurikulum tidak sampai pada peserta didik. Selain itu, juga dikarenakan profesionalitas guru adalah sebuah keniscayaan maka guru baru dinilai layak mendapat prestise "profesional" pada saat memiliki kamampuan dan keahlian khusus dalam bidang keguruan sehingga mampu melakukan tugas dan fungsinya sebagai guru dengan kemampuan maksimal (Usman, 2007, hlm. 15). Dalam buku "Pendidikan Menuju 2025" disebutkan bahwa kualifikasi pendidik dan tenaga kependidikan diklasifikasikan sebagai salah satu utama permasalahan Indonesia yang aktual, mendesak dan berdampak nasional (Suryadi, 2014, hlm. 13).

Oleh karenanya, mesti ada upaya pembentukan profesionalitas guru yang sistematis, radikal dan menjunjung prinsip kontinuitas. Pembentukan empat kompetensi ini dilalui oleh calon guru pada tahapan preservice education selama delapan semester. Profesionalitas guru yang dimaksud tertera dalam UU Guru dan Dosen dimana guru harus menguasai empat jenis kompetensi, yaitu kepribadian, pedagogik, profesional dan sosial. Tidak berhenti disitu, meskipun telah mendapatkan kualifikasi minimal D-IV atau S1 Kependidikan, profesionalitas guru dinilai belumlah cukup. Peningkatan kompetensi guru harus terus dikembangkan melalui tahap in sevice training. Pada tahap ini guru dituntut harus mengembangkan kompetensi diri melalui program peningkatan kompetensi guru lainnya.

Namun demikian, persoalan yang tak pernah lepas dari setiap pergantian kurikulum adalah perubahan kurikulum 
dilakukan seakan tanpa mempertimbangkan kompetensi guru. Apakah guru dinilai mampu menyampaikan substansi kurikulum. Karena guru adalah aktor utama yang mengimplementasikan kurikulum yang telah didesain. Sebagus apapun naskah skrip yang telah disusun, akan tetapi tanpa kelihaian aktor dalam menyampaikan isi naskah, menyuguhkan trik maka naskah tak bernilai apa-apa. Begitu juga halnya guru, seideal apapun kurikulum yang dirumuskan namun tanpa kefasihan guru mamahani materi ajar, tanpa kecakapan guru dalam menggunakan berbagai strategi dan metode pembelajaran agar materi mudah dipahami peserta didik dan tanpa keterampilan dalam mengevaluasi tingkat pencapaian tujuan pembelajaran maka kurikulum tak benarbenar menjadi milik peserta didik.

Tulisan ini bertujuan ingin menekankan pada upaya peningkatan profesionalisme guru adalah benar-benar penting. Selama ini persepsi yang beredar di masyarakat bahwa kita beberapa waktu belakang terlalu disibukkan dengan persoalan pergantian kurikulum. Alhasil, konsentrasi untuk bagaimana caranya meningkatkan diri sebagai guru dan mutu guru menjadi terkuras habis. Menarik untuk dikaji, maka tulisan membatasi fokus kajian pada tiga hal, antara lain Pertama, mutu guru yang terabaikan dikaji dari pencapaian program profesionalisasi guru, diantaranya kualifikasi dan sertifikasi guru serta program pendidikan dan uji kompetensi guru. Kedua, beberapa persoalan yang diketengahkan akibat minimnya kadar pencapaian profesionalisasi guru sebagai tonggak utama keberhasilan kurikulum. Ketiga, alur pembenahan hendaknya diinisiasi dari peningkatan mutu guru, kemudian atas dasar itu dibangun kontruksi kurikulum dan peserta didik mampu mereguh esensi kurikulum.

\section{B. KAJIAN LITERATUR}

1. Urgensi Mutu Guru dalam Perencanaan dan Implementasi Pembelajaran

Apapun kurikulum, mutu guru adalah kuncinya. Ibarat pusaran air pendidikan, guru adalah pusatnya. Semua aliran tertuju pada guru. Guru memegang peran yang sangat sentral. Baik buruknya semua komponen pendidikan seperti peserta didik, sarana prasarana, tetap saja guru adalah pemegang kendalinya. Pencapaian keberhasilan peserta didik yang tinggi tentu tidak lepas dari seperti apa gurunya. Ketidaktersediaan sarana prasarana yang memadai, bukanlah hal yang penentu keberhasilan peserta didik. Banyak juga kasus mengatakan bahwa ketidaktersediaan sarana prasarana yang serba cukup namun tidak dapat menggenjot hasil pembelajaran peserta didik. Seideal apapun kurikulum yang didesain, sehebat apapun orang yang merancang, mutu guru adalah penentunya.

Hal yang sama diungkapkan Mantan Menteri Pendidikan dan Kebudayaan Fuad Hasan (Kunandar, 2007:42-43), sebaik apapun kurikulum dan sistem pendidikan yang ada, tanpa didukung oleh mutu guru yang memenuhi syarat maka semuanya akan sia-sia. Lebih lanjut dikatakan bahwa peningkatan mutu pendidikan di Indonesia tidak cukup dengan pembenahan di bidang kurikulum saja, tetapi harus juga diikuti dengan mutu guru di jenjang dasar tingkat dasar dan menengah. Tanpa upaya meningkatkan mutu guru, semangat tersebut tidak akan mencapai harapan yang diinginkan. Ismail (2010) mamandang guru adalah sumber daya yang aktif sedangkan sumber-sumber daya lain adalah sumber daya yang pasif. Oleh karena itu, sebaik-baik apapun kurikulum, saran prasarana, fasilitas jika 
kualitas gurunya rendahnya maka akan sulit untuk mendapatkan hasil pendidikan yang bermutu tinggi. Konklusinya adalah baik buruknya semua elemen komponen pendidikan maka yang menjadi faktor determinan adalah guru. Selama faktor determinan ini tidak betul-betul diperhatikan, maka faktor-faktor lain tidak akan berfungsi secara optimal walau kondisi faktorfaktor lain tersebut bagus.

Jangan bermimpi menghadirkan guru yang profesional, kecuali persyaratan pendidikan, kesejahteraan, perlindungan dan pemartabatan mereka terjamin (Danim, 2011:2). Kemampuan dan keterampilan guru diduga akan mempengaruhi hasil belajar peserta didik. Apabila kemampuan dan keterampilan yang dimiliki guru rendah, tendensi akan mengarah pada kualitas hasil belajar peserta didik yang rendah pula dan sebaliknya (Agung, 2014:10). Maka agar peserta didik mampu mengembangkan potensi yang ada dalam dirinya dan memneuhi cita-cita pendidikan bangsa, tentu guru profesional adalah harga mati. Dikatakan guru profesional karena didalamnya sudah dikuasai sejumlah kompetensi yang dibutuhkan. Kompetensi diartikan sebagai pengetahuan, keterampilan dan nilainilai yang direfleksikan dalam kegiatan berpikir dan bertindak. Kompetensi tersebut akan terwujud dalam penguasaan pengetahuan dan perbuatan secara profesional dalam menjalankan fungsi sebagai guru (Suparlan, 2005:93). Lebih lugas diterangkan, bahwa kompetensi menggambarkan kemampuan bertindak dilandasi ilmu pengetahuan yang hasil dari tindakan itu bermanfaat bagi dirinya dan bagi orang lain (Sagala, 2013:157). Kurikulum yang akan diterapkan guru kepada peserta didik mengandung empat komponan utama (Nasution, 2001:18), yakni tujuan, bahan, proses belajar mengajar dan evaluasi). Agar kurikulum (tujuan, bahan, proses dan evaluasi pembelajaran) dapat dirasakan manfaatnya oleh peserta didik, maka dibutuhkan dan kemudian disusun sejumlah kompetensi tertentu. Suparlan memandang ada 5 kompetensi dasar yang harus dikuasai guru yaitu menguasai materi atau bahan ajar, antusiasme, penuh kasih sayang, strategi atau metode dan penilaian pembelajaran (Suparlan, 2005: 99-100).

2. Faktor-Faktor Penghambat Mutu Guru Setiawan (2017) dalam penelitiannya menemukan bahwa faktor-faktor penghambat peningkatan profesionalisme guru di tingkat Pendidikan Dasar di Sumatera Utara, khususnya Kabupaten Batubara adalah: Pertama, regulasi terhadap pengawas belum diatur secara mengikat; regulasi terhadap pendidikan dan pelatihan, mulai dari perencanaan, pelaksanaan, dan evaluasi juga belum dituangkan dalam suatu rencana kerja, serta regulasi pemberian reward dan punishment guru belum diatur; Kedua, kegiatan-kegiatan sekolah untuk meningkatkan profesionalisme guru, mulai workshop, mengikuti seminar, diskusi ilmiah, inhouse traning melalui $\mathrm{KKG} / \mathrm{MGMP}$, ataupun kegiatan lainnya belum tersistem ataupun terprogram pada program dan kegiatan di Dinas Pendidikan. Kegiatankegiatan tersebut hanya dilakukan pada momen-momen tertentu saja dan tidak berkelanjutan; Ketiga, peningkatan kompetensi guru di daerah masih difokuskan pada 2 (dua) kompetensi, yaitu profesional dan pedagogik guru, sementara untuk 2 (dua) kompetensi guru lainnya, kepribadian 
dan sosial guru belum menjadi prioritas Dinas Pendidikan di daerah; Keempat, reward dan punishment bagi guru belum menjadi fokus perhatian penting oleh Dinas Pendidikan, sehingga berdampak pada motivasi dan kinerja guru sebagai pendidik dan pengajar yang profesional.

\section{METODOLOGI PENELITIAN}

Metode penelitian yang digunakan adalah library research dengan menelaah sejumlah literatur. Namun untuk memperkuat maka penulis menyodorkan beberapa data hasil wawancara, observasi dan pengalaman empirik. Alur penyusunan tulisan dimulai dengan menuliskan deskripsi mutu guru melalui program profesionalisasi guru didasarkan pada data dokumentasi. Data dokumentasi yang disuguhkan adalah gambaran guru di salah satu daerah remote area di Indonesia. Kemudian atas dasar ini dikemukakan persoalan yang timbul akibat mutu guru yang rendah didasarkan pandangan pribadi didukung oleh observasi, pengalaman pribadi dan beberapa literatur terkait. Terakhir, dilakukan mengemukakan alur pembenahan sebenarnya dimulai dari mana diantara ketiga elemen, yakni peserta didik, guru atau kurikulum.

\section{HASIL DAN PEMBAHASAN}

1. Menakar Mutu Guru dari Ketercapaian Program Peningkatan Profesionalisme Guru

Sebagai bentuk telaah lebih radikal dan pembuktian bahwa teori yang dibangun bahwa mutu guru memegang peran yang sentral dalam implementasi kurikulum maka penulis menyuguhkan sampel data dokumentasi tentang seperti apa pencapaian program profesionalisme guru di daerah salah satu remote area di Indonesia. Ada tiga fungsi utama guru dalam pembelajaran yaitu sebagai perencana (planner), pelaksana dan pengelola (organizer) dan penilai (evaluasi) (Suyono, 2015:189). Sebagai pelaksana dan pengelola agar kurikulum sampai kepada peserta didik, maka tentu dibutuhkan sejumlah kompetensi. Kompetensi ini dapat dikuasai melalui progam profesionalisme guru. Program ini terdapat empat ranah yang dimaksudkan untuk mewujudkan guru yang benar-benar profesional. Keempat ranah yang dimaksud sebagai berikut: Pertama, penyediaaan guru berbasis perguruan tinggi. Kedua, induksi guru pemula berbasis sekolah. Ketiga, profesionalisasi guru berbasis prakarsa institusi. Keempat, profesionalisasi guru berbasis individu (Danim, 2011:3).

a. Kualifikasi Guru

Guru dalam menjalankan tugasnya sebagai implementator tampak jelas pada seperti apa kurikulum diterapkan pada tingkat kelas. Dakir memandang pada tingkat ini tergantung pada keinisiatifan guru. Meskipun kurikulum tertulis yang ada sangat bagus, tetapi kalau ada di tangan guru yang tidak berinisiatif maka hasilnya tidak akan memuaskan. Sebagaimana ungkapan not the song but the singer (Dakir, 2010:103). Untuk itu, dalam UU No 14 tahun 2005 Pasal 8 menyatakan guru wajib memiliki kualifikasi akademik, kompetensi, sertfikat pendidik, sehat jasmani dan rohani serta memiliki kemampuan mewujudkan tujuan pendidikan nasional. Kemudian pada pasal 9 menyatakan kualifikasi akademik sebagaimana yang dimaksud pada pasal 8 diperoleh melalui pendidikan tinggi program sarjana atau diploma empat. Penegasan dari UU ini menyatakan secara jelas bahwa kualifikasi guru setidaknya berpendidikan sarjana atau diploma empat. 
Kualifikasi akademik adalah ijazah jenjang pendidikan akademik yang harus dimiliki oleh guru atau dosen sesuai dengan jenis, jenjang, dan satuan pendidikan formal di tempat penugasan. Barnwai dan Arifin berpendapat bahwa diantara prinsipprinsip profesionalitas yang harus dimiliki setiap guru adalah memiliki kualifikasi akademik dan latar belakang pendidikan yang sesuai dengan bidang tugas. Profesi membutuhkan latar belakang yang spesifik. Oleh karena itu, latar belakang akademik yang linear dengan bidang pekerjaan sangat dibutuhkan (Arifin, 2012:37).

Kualifikasi akademik hendaknya tak diartikan oleh calon guru sebagai selembar ijazah semata tanpa memaknai setiap proses pembelajaran yang dilalui. Karena kualifikasi akademik merupakan upaya membentuk guru yang benar mempunyai kompetensi unggul dan menjadi ahli (expert) di bidangnya karena profesi guru bukanlah profesi sembarangan yang siapa saja bisa memasukinya. Karena profesi mengandung keahlian khusus bukan hal yang diwarisi, dan menuntut keterampilan tertentu yang diperoleh lewat pendidikan dan latihan yang lama dan intensif serta didukung oleh suatu disiplin ilmu bukan sekedar serpihan atau akal sehat semata (Hosnan, 2016:9). Dengan demikian, ijazah (termasuk akta, sertifikat) merupakan bentuk pengakuan secara formal yang diberikan Lembaga Pendidikan dan Tenaga Kependidikan (LPTK) terhadap guru yang sudah dinilai profesional dalam menjalankan tugas nantinya.

Kualifikasi akademik yang telah diatur belum sepenuhnya dapat terlaksana disebabkan beberapa kondisi dan masih butuh waktu lagi meskipun tentu aturan ini sudah mengikat, diketahui dan diterapkan pada seluruh daerah di Indonesia. Kebijakan pemerintah dalam arti yang positif didasarkan pada peraturan perundang-undangan dan bersifat memaksa atau otoritatif (Hasbullah, 2015:39). Salah kondisi disinyalir menjadi penyebab adalah masih tidak tersebar ratanya sumber daya guru di Indonesia terutama daerah yang dikategorikan remote area, yaitu: bahwa guru yang berijasah sarjana pendidikan atau diploma empat 66\%, sedangkan guru yang berijasah DIII/S1 Non Kependidikan 31\% dan 3\% adalah guru yang hanya tamatan SMA. Hal ini terlihat dari gambaran data berikut:

Tabel 1

Kualifikasi Guru Antara S1/D-IV Pendidikan Dengan Non Kependidikan
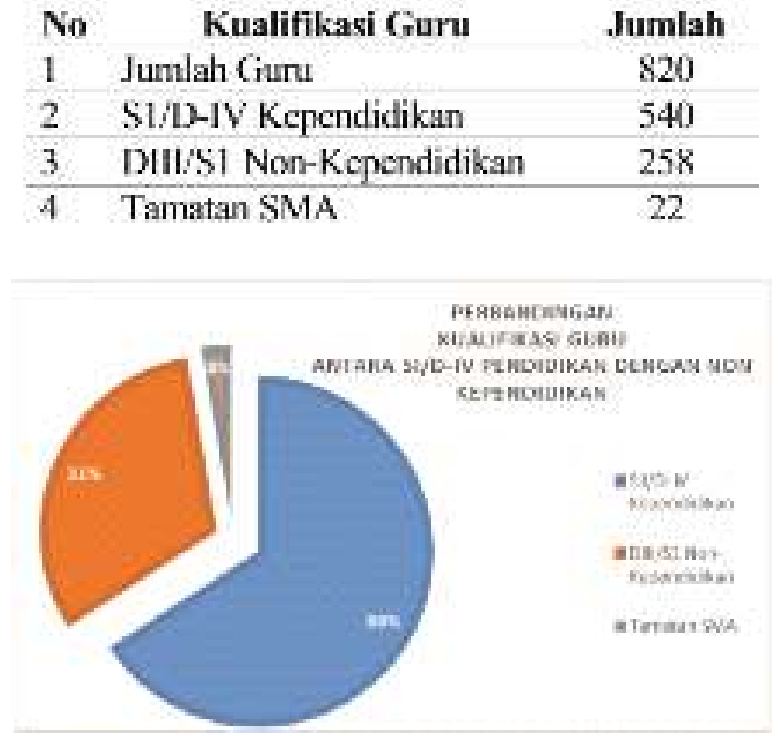

Sumber: Dinas Pendidikan Kabupaten Daerah Remote Area yang Diteliti

Gambar 1

Kualifikasi Guru Antara S1/D-IV Pendidikan Dengan Non Kependidikan 
b. Sertifikasi Guru

Dalam UU No 14 tahun 2005 tentang Guru dan Dosen dikemukakan bahwa sertifikasi adalah proses pemberian sertifikat pendidik untuk guru dan dosen. Sedangkan sertifikat pendidikan adalah bukti formal sebagai pengakuan yang diberikan kepada guru dan dosen sebagai tenaga profesional. Guru profesional adalah guru yang menyadari tugas dan fungsinya sesuai dengan jabatan yang diembannya, memiliki pemahaman yang tinggi serta mengenal dirinya sebagai pribadi yang dipanggil untuk mengabdikan diri kepada masyarakat melalui pendidikan dan mendampingi peserta didik belajar (Mulyasa, 2015:40).

Berdasarkan pengertian tersebut, sertifikasi guru dapat diartikan sebagai suatu proses pemberian pengakuan bahwa seseorang telah memiliki kompetensi untuk melaksanakan pelayanan pendidikan pada satuan pendidikan tertentu, setelah lulus uji kompetensi yang diselenggarakan oleh lembaga sertifikasi (Mulyasa, 2012: 33-34). Sebagai sebuah pengakuan atas kompetensi guru, maka angka guru yang mendapatkan pengakuan dapat diilihat data data berikut:

Tabel 2

Perbandingan Antara Guru Sudah Dengan Belum Sertifikasi

\begin{tabular}{llc}
\hline No & \multicolumn{1}{c}{ Sertifikasi Guru } & Jumlah \\
\hline 1 & Jumlah Guru & 818 orang \\
\hline 2 & Guru Sudah Sertifikasi & 163 orang \\
\hline 3 & Guru Belum Sertifikasi & 655 orang
\end{tabular}

Pada kabupaten daerah remote area ini, dapat digambarkan bahwa guru yang sudah diakui kompetensinya secara formal tidak sebanding dengan yang sudah diakui.
Tentu hal ini akan berpengaruh pada ketercapaian implementasi kurikulum dan hasil belajar peserta didik. Jika dikalkulasikan maka guru yang benarbenar diakui berkompetensi di kabupaten ini dalam mengajar hanyalah $20 \%$ sedangkan yang belum diakui adalah $80 \%$. Tidak salah bilamana laju perkembangan pendidikan di kabupaten remote area dinilai lambat. Meskipun harus diakui dari sejumlah hasil penelitian dan realita di lapangan, bentuk pengakuan kompetensi guru melalui sertifikasi tidak selalu mencerminkan kompetensi guru. Meskipun, sertifkasi guru bukanlah faktor satu-satunya yang penyebab pencapaian hasil belajar peserta didik dan laju pertumbuhan pendidikan.

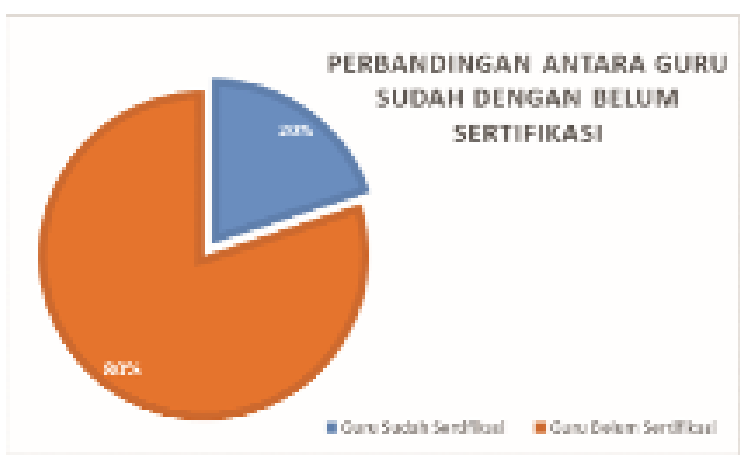

Sumber: Dinas Pendidikan Kabupaten Daerah Remote Area yang Diteliti

Gambar 2

Perbandingan Antara Guru Sudah dengan Belum Sertifikasi

c. Program Pendidikan Profesi Guru

Pendidikan Profesi Guru adalah program pendidikan yang diselenggarakan untuk lulusan S1 Kependidikan atau S1/D-IV Non Kependidikan yang memiliki bakat dan minat menjadi guru agar mereka dapat menjadi guru yang profesional serta memiliki kompetensi secara utuh sesuai dengan standar nasional 
pendidikan. PPG merupakan pendidikan tinggi setalah program pendidikan sarjana yang mempersiapkan pesrta didik untuk memiliki pekerjaan dengan persyaratan keahlian khusus menjadi guru yang dilalui selama 2 semester atau 1 tahun (Hosnan, 2016: 264-265). Namun pada daerah remote area data ini didapatkan, belum ada satu gurupun yang telah mengikuti program PPG.

d. Uji Kompetensi Guru

Permendibud No 57 tahun 2012 mengatakan bahwa Uji Kompetensi Guru (UKG) merupakan pengujian terhadap kompetensi profesional dan pedagogik dalam ranah kognitif sebagai dasar penetapan kegiatan pengembangan keprofesian berkelanjutan dan bagian dari penilaian kinerja guru. UKG melambangkan tingkat kompetensi yang telah dikuasai guru. Rendahnya UKG di Indonesia dipengaruhi lagi dengan maraknya jual beli gelar yang menghasilkan gelar dan ijasah palsu yang dilakukan oleh dunia pendidikan tinggi yang tidak bertanggung jawab seakan memfasilitasi keinginan masyarakat yang malas bersusah payah, sehingga menyebabkan kompetensi guru rendah. Hal ini dapat dilihat dari data kegiatan UKG. Nilai standar yang sudah ditetapkan oleh pemerintah pusat, yaitu 55 dan ini tidak ada peningkatan yang signifikan yang diperoleh oleh guru yaitu 55, 6 dan ini menandahkan bahwa tidak ada perubahan. Merujuk dari data yang didapatkan, maka rata-rata nilai UKG pada 11 mata pelajaran adalah 55,56. Bilamana dipetakan maka hanya satu cukup memuaskan kompetensinya yakni TIK dengan rata-rata nilai 71,9 . Rapor merah yang diperoleh guru ini merupakan mungkin agar guru dapat menjalankan fungsinya lebih optimal. yang dinilai jawaban jujur atas tingkat profesionalisme guru. Hal ini mesti diperbaiki segera mungkin agar guru dapat menjalankan fungsinya lebih optimal.

Tabel 3

Hasil Uji Kompetensi Guru

\begin{tabular}{|c|c|c|c|c|}
\hline Nin & Mata Najajuras & $\begin{array}{l}\text { Pescrla } \\
\text { UIEL: }\end{array}$ & $\begin{array}{c}\text { Nilui Di Alas } \\
\text { Raba-Hata }\end{array}$ & $\begin{array}{l}\text { Nhine Di Burnt } \\
\text { Mata-kaiz }\end{array}$ \\
\hline 1 & Fkin & 420 rere & 33 owirg & 9 orars \\
\hline \multicolumn{3}{|c|}{ Nat HataI } & \multicolumn{2}{|r|}{5676} \\
\hline 1 & Malanuab: & Pinam & 42 ca:ald & 37 sart \\
\hline \multicolumn{3}{|c|}{ Nath fouta? } & \multicolumn{2}{|r|}{55,55} \\
\hline 3 & IFA & Kincing & "finrong & 2Tarare \\
\hline \multicolumn{3}{|c|}{ Nifal lleata2 } & \multicolumn{2}{|r|}{51.15} \\
\hline 4 & Bine lepero & 83 wion & 14 viris & GSuretg \\
\hline \multicolumn{3}{|c|}{ Nand Rata? } & \multicolumn{2}{|c|}{2825} \\
\hline 2 & Husa bransin & il irasts. & 11 crese & Abarar: \\
\hline \multicolumn{3}{|c|}{ NBin louls: } & \multicolumn{2}{|c|}{53.68} \\
\hline 6 & IFS & $87 \mathrm{\alpha oog}$ & 7) corm? & $8 \cos$ \\
\hline \multicolumn{3}{|c|}{ Natal Hata2 } & \multicolumn{2}{|r|}{91.42} \\
\hline 7 & $7 \mathrm{TK}$ & 21 wail & 40.246 & 17 enrs \\
\hline \multicolumn{3}{|c|}{ Nane Rate? } & \multicolumn{2}{|c|}{$99,1 \mathrm{~W}$} \\
\hline \multirow[t]{2}{*}{1} & Pendatiban terera & young & 3 and & 22 arare \\
\hline & \multicolumn{2}{|l|}{ Nilat Ioila: } & \multicolumn{2}{|c|}{$4 \times 65$} \\
\hline \multirow[t]{2}{*}{ y } & Szri kspa & Sonef & 20 ave & $1 \mathrm{oran}$ \\
\hline & \multicolumn{2}{|l|}{ NGai HataI } & \multicolumn{2}{|c|}{$51.7 \mathrm{~K}$} \\
\hline \multirow[t]{2}{*}{10} & Scti Musik & 3 anath. & Aunas & 3 แ4⿺辶⿻ \\
\hline & & & \multicolumn{2}{|c|}{7.9} \\
\hline II & Simingen Kincling & lurreng & 2 ams & 17ange \\
\hline \multicolumn{3}{|c|}{ Notat Itatat } & \multicolumn{2}{|c|}{5462} \\
\hline & Nilai Ram? Keschs & $\tan$ & & 866 \\
\hline
\end{tabular}

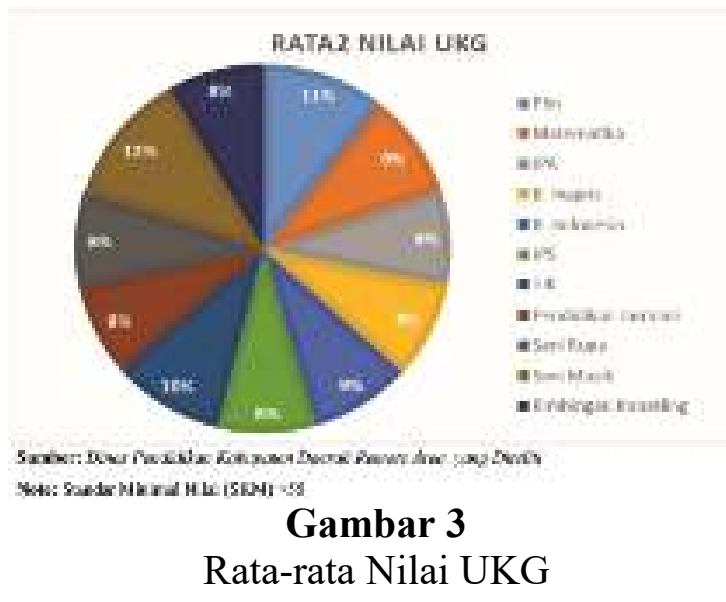

2. Persoalan yang Timbul Akibat Kadar Pencapaian Profesionalisasi Guru yang Minim 
Terjadi kerancuan berpikir bilamana kurikulum yang dirumuskan dan kemudian diimplementasikan tanpa mempertimbangkan kompetensi guru. Dalam kondisi objektif implementasi kurikulum 2013 maka kembali mutu guru menjadi sasaran empuk sorotan mata publik setiap pergantian kurikulum. Membandingkan kurikulum 2013 dan 2006, ada beberapa perubahan dalam kurikulum 2013 yang mendasar, antara lain: Pertama, peserta didik mulai dari Sekolah Dasar diterapkan pendekatan High Order Thingking Skills (HOTS). Kedua, setiap guru mata pelajaran diwajibkan mengajar Kompetensi Inti 1 dan Kompetensi Inti 2 tidak hanya Kompetensi Inti 3 dan Kompetensi Inti 4. Anak tetapi, realita yang terjadi di lapangan pada beberapa tempat, guru tak sepenuhnya dipersiapkan untuk ini. Data observasi dan wawancara yang didapatkan menyebutkan bahwa guru mengalami kesulitan dalam bagaimana (how) menerapkan dua hal ini dan tidak menguasai betul apa (what) yang ingin diajarkan kepada peserta didik.

Dalam ungkapan yang lebih sederhana, bagaimana guru dapat mencapai hasil belajar pada taraf mencipta tidak hanya mengetahui dan memahami (HOTS) akan tetapi guru tidak menguasai betul konsep HOTS (what and how) pada mata pelajaran yang diampunya. Ditambah lagi, bagaimana guru mampu optimal mengajarkan KI 1 (sikap spiritual) dan KI 2 (sikap sosial) terutama pada mata pelajaran umum dimana guru tidak mendapatkan pengetahuan yang komprehensif tentang ini. Guru mata pelajaran umum dinilai hanya menguasai KI 3 dan KI 4 dann itupun sudah kewalahan dalam mengajarkan apalagi harus mengkorelasikan KI 1 dan KI 2 dalam mata pelajaran umum. Selain itu, juag harus disadari minimnya literatur yang mengkaji khusus apa dan bagaimana menerapkan KI 1 sampai KI 4 pada mata pelajaran umum dalam satu waktu.

Oleh karena itu, Yunus Abidin memandang bahwa ada sejumlah tantangan dalam implementasi kurikulum 2013, yaitu: Pertama, guru harus mampu menyelenggarakan pendidikan dengan berorientasi pada aktivitas siswa dalam menemukan dan menetapkan makna secara mandiri sehingga proses pembelajaran akan mampu membentuk kemampuan berpikir tingkat tinggi atau HOTS; Kedua, guru harus melaksanakan pembelajaran dengan menetapkan model pembelajaran aktif berbasis proses saintifik sebagai pembelajaran utama yang digunakan; Ketiga, guru haruslah orangorang yang benar-benar kapabel di bidangnya; Keempat, guru seyogyanya harus benar-benar mampu untuk menemukan cara untuk mendorong dan mengembangkan pemenuhan seluruh kebutuhan siswa berdasarakn potensi yang dimilikinya. Tanpa usaha ini, akan sulit tercipta lulusan yang berbekal kemampuan membaca pemahaman yang tinggi berbasis kemampuan berpikir yang tinggi (Abidin, 2014:26-27).

Tantangan ini hendaknya sudah diperhitungkan pada saat kurikulum dirancang dan sebelum diimplementasikan. Pertanyaannya adalah apakah pada saat perumusan kurikulum 2013 juga dirumuskan bagaimana cara implementator menerapkannya. Aktualnya, seperti apa rumusan langkahlangkah yang akan dilakukan guru dalam menerapkan HOTS pada setiap mata pelajaran, mulai jenjang sekolah dasar sampai sekolah menengah atas. Artinya HOTS memang betul didesain agar peserta didik mampu berpikir sampai pada tahap mencipta namun yang lebih penting adalah didesain bagaimana guru juga mempunyai kerangka berpikir pembelajaran berbasis 
HOTS. Karena bagaimana mungkin kurikulum yang didesain agar peserta didik berpikir dengan HOTS akan tetapi guru yang orang yang menerapkan tidak menguasai what dan how menerapkan pendekatan HOTS kepada peserta didik. Pada tingkat sekolah dasar, peserta didik dituntut juga mampu berpikir tinggi melalui mencipta sesuatu (HOTS) tidak sebatas mengetahui. Misal membuat alat peraga sederhana seperti layangan. Maka guru hendaknya harus mengetahui bentuk layangan yang ingin dibuat dan cara-cara membuat layangan kemudian baru dapat diajarkan kepada peserta didik.

Nana Sudjana menegaskan bahwa bagaimanapun baiknya kurikulum belum menjamin menghasilkan lulusan yang terbaik seperti yang diinginkan kurikulum itu sendiri. Karena sejatinya proses sampainya kepada siswa tergantung kepada pelaskana kurikulum, yaitu guru. Gurulah yang menentukan sampai atau tidaknya niat dan harapan yang ada dalam kurikulum tersebut. Maka tugas dan tanggung jawab guru dalam hubungannya dengan kurikulum adalah menjabarkan dan mewujudkan kurikulum potensial menjadi kegiatan nyata (aktual) di dalam kelas melalui proses belajar mengajar (Sudjana, 2013: 16-17).

Selain itu, dilihat dari sudut pandang delapan standar pendidikan maka standar proses pendidikan (SPP) merupakan jantungnya dalam sistem pendidikan. Bagaimanapun bagusnya dan idealnya standar kompetensi lulusan serta lengkapnya standar isi, namun tanpa diimplementasikan ke dalam proses pendidikan, maka semauanya tidak berarti apa-apa. Maka dalam hal ini, guru memainkan peran yang sangta penting. Hal ini disebabkan keberhasilan implementasi standar proses pendidikan itu sangat ditentukan oleh kemampuan guru, sebab guru merupakan orang pertama yang berhubungan dengan pelaksanaan program pendidikan. Oleh sebab itu, dalam implementasi SPP guru perlu memahami sekurang-kurangnya dalam tiga hal, yakni: Pertama guru perlu memahami perencanaan program pendidikan yaitu menyangkut pemahaman dalam menjabarkan isi ke dalam bentuk silabus yang dapat dijadikan dalam pembelajaran; Kedua, pemahaman dalam bentuk pengelolaan pembelajaran termasuk dalam desain dan implementasi strategi pembelajaran yang sesuai dengan tujuan dan isi pendidikan; Ketiga, pemahaman tentang evaluasi proses maupun hasil pembelajaran (Sanjaya, 2006: 10-11). Sementara itu, E. Mulyasa memandang setiap implementasi kurikulum, pada dasarnya menuntut guru untuk menguasai isi bidang studi, pemahaman karakteristik peserta didik, melakonkan pembelajaran yang mendidik dan menyenangkan dan potensi pengembangan profesionalisme dan kepribadian (Mulyasa, 2015:5).

Dengan demikian, persoalan yang muncul akibat kadar pencapaian profesionalisasi guru yang minim adalah pencapaian tujuan, isi, strategi dan evaluasi dipertanyakan. Maka dari pada itu, seharusnya agar implementasi kurikulum dapat terlaksana dengan baik, maka salah satunya harus merujuk pada keyakinan dengan data ilmiah bahwa perubahan kurikulum harus bisa dikelola dan dilaksanakan oleh sebagian besar guru. Karena faktor penting yang mempengaruhi keberhasilan kurikulum adalah implementator. Maka guru sebagai implementator harus mempunyai dua pemahaman berikut, yakni: Pertama, pemahaman tentang karaktersitik perubahan kurikulum; Kedua, pemahaman tentang kaitan antara perubahan kurikulum dengan perubahan konteks sosial- 
institusional atau kultur sekolah yang baru (Ansyar, 2015:410).

Agar profesionalisme guru berkembang dan meningkat maka guru hendaknya memperhatikan faktor-faktor sebagai berikut, antara lain faktor kepemimpinan kepala sekolah yang demokratis, iklim kerja di sekolah kondusif, dukungan positif dari anggota keluarga guru di rumah terhadap aktivitas mengajar di sekolah, dukngan moral dari dewan sekolah, komite sekolah, peserta didik, dan masyarakat terhadap pengabdian guru dalam mengajar di sekolah, dukungan biaya pendidikan yang memadai dari orangtua peserta didik, masyarakat, dan pemerintah, dukungan infrastruktur dan fasilitas pendidikan dari orangtua peserta didik, masyarakat, dan pemerintah, dan dukungan berbagai sumberdaya pendidikan lainnya dari para stakeholders pendidikan di sekolah (Nuhayati, 2006). Karena faktor-faktor ini dinilai juga mempengaruhi profesionalisme guru di lapangan selain faktor kompetensi guru itu sendiri.

$$
\text { Selain itu, Murwati (2013) }
$$
berpendapat bahwa agar profesionalisme guru dapat berkembang maka guru agar lebih membangun motivasi kerja yang lebih baik dalam bentuk internal maupun eksternal, maka disarankan guru lebih terbuka dalam menerima tugas sebagai guru, disamping dilandasi kesejahteraan guru juga dilandasi karena suatu pengabdian dan tanggung jawab. Tidak hanya itu, guru disarankan untuk benarbenar mengaplikasikan ilmu yang didapat dari program sertifikasi guru, misalnya mendemonstrasikan kompetensi secara riil di kelas yakni mulai dari tahap perencanaan, pelaksanaan, hingga tahap penutupan dalam siklus pembelajaran.

3. Alur Pembenahan Pendidikan antara Guru, Peserta Didik dan Kurikulum
Memahami urgensi guru terhadap implementasi kurikulum dan peserta didik, maka mestinya mutu guru yang harus diinisasi untuk ditingkatkan profesionalisme terlebih dahulu. Wina Sanjaya memandang bagaimanapun idealnya kurikulum tanpa ditunjang oleh kemampuan untuk mengimplementasikan nya, maka kurikulum itu tidak akan bermakna sebagai suatu alat pendidikan dan sebaliknya, pembelajaran tanpa kurikulum sebagai pedoman tidak akan efektif. Dengan demikian, peran guru dalam mengimplementasikan kurikulum memegang posisi kunci (Sanjaya, 2013:28).

Dalam perumusan kurikulum, hendaknya dirujuk dulu seperti apa mutu guru sekarang dan apakah rumusan kurikulum yang dirancang mampu diterapkan guru, apakah tidak terlalu berat bagi guru atau guru belum siap dengan rumusan tersebut. Selain itu, hal yang penting lagi adalah setelah rumusan kurikulum telah selesai didesain sesuai dengan kebutuhan peserta didik, maka perlu juga hendaknya disusun rumusan kompetensi apa yang harus dikuasai guru dan pedoman berupa langkah-langkah yang dapat menjadi rujukan dalam menerapkan kurikulum di kelas. Alhasil, guru betul-betul memahami apa (what) esensi kurikulum (tujuan dan evaluasi) serta tidak mengalami kebingungan bagaimana bagaimana (how) dalam menerapkannya (metode dan evaluasi).

Bilamana belajar dari masa lampau, yakni pada tahun 1862 di Inggris, ketika kurikulum diperluas dalam penyusunannya. Pada awalnya kurikulum di hanya terdiri dari pelajaran agama dan tiga pelajaran dasar (membaca, menulis dan berhitung). Namun kemudian, kurikulum dipeluas berdasarkan pada filosofi yang sudah dipertimbangkan semata, namun juga melainkan kualifikasi 
guru (Hughes, 2015: 326-327). Maka seyogyanya pada saat kurikulum dirumuskan maka tidak hanya didasari pada pertimbangan kebutuhan peserta didik saja namun juga kompetensi guru.

\section{E. SIMPULAN DAN SARAN}

Hasil telaah dan kajian penelitian ini mengutarakan beberapa rekomendasi untuk upaya peningkatan mutu guru di Indonesia, antara lain: Pertama, data yang menerangkan tentang ketercapaian program profesionalisme guru yang melingkupi kualifikasi akademik, sertifikasi guru, program profesionalisme guru dan uji kompetensi guru terbilang rendah yang kemudian berpotensi terhadap efektifitas implementasi kurikulum; Kedua, persoalan yang timbul akibat kadar pencapaian profesionalisasi guru yang minim adalah penerapan tujuan, isi, metode dan evaluasi kurikulum tak berjalan sebagaimana mestinya; Ketiga, alur pembenahan pendidikan hendaknya dimulai dari peningkatan mutu guru. Selain itu, dalam perumusan kurikulum hendaknya pada waktu yang bersamaan juga dirumuskan kompetensi guru apa saja yang disyaratkan dalam desain kurikulum serta disusun pedoman bagi guru berupa langkahlangkah menerapkan kurikulum. Alhasil, peserta didik dapat mereguh esensi kurikulum.

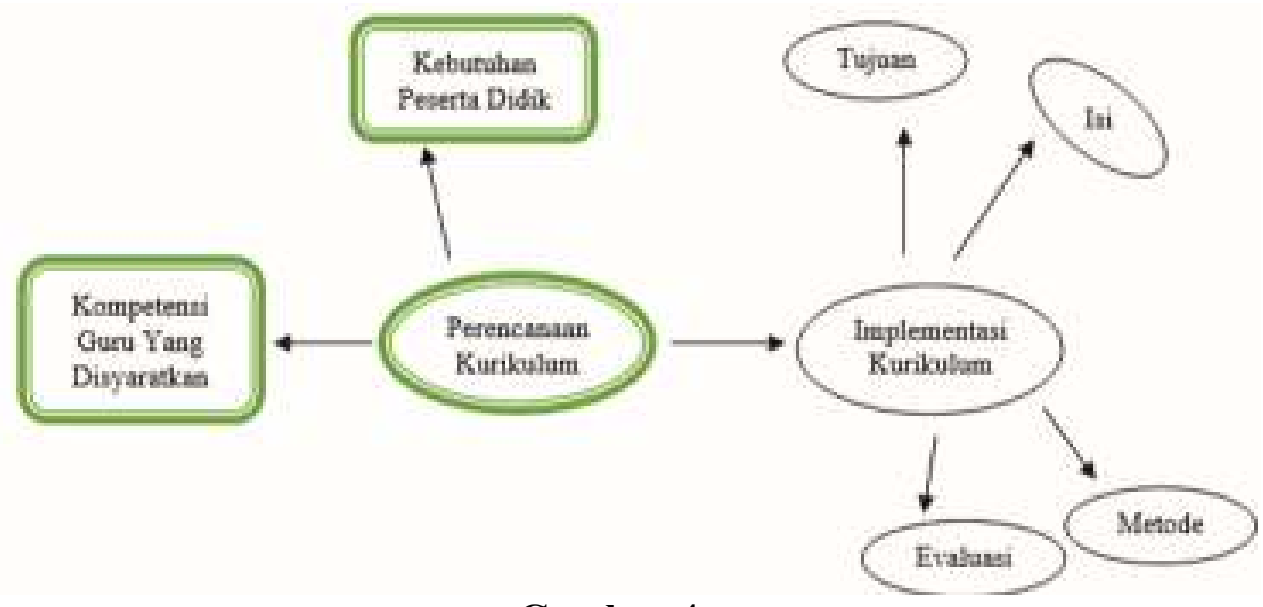

Gambar 4

Alur Pembenahan Pendidikan Antara Guru, Peserta Didik dan Kurikulum

\section{DAFTAR PUSTAKA}

Abidin, Y. (2014). Desain Sistem Pembelajaran Dalam Konteks Kurikulum 2013. Bandung: PT. Refika Aditama.

Agung, I. (2014). Mengembangkan Profesionalitas Guru. Jakarta: Bee Media Pustaka.

Ansyar, M. (2015). Kurikulum: Hakikat, Fondasi, dan Desain Pengembangan. Jakarta: Kencana Prenada Media Group.
Arifin, B. d. (2012). Etika dan Profesi Kependidikan. Jogjakarta: Ar Ruz Media.

Dakir. (2010). Perencanaan dan Pengembangan Kurikulum. Jakarta: PT. Rineka Cipta.

Danim, S. (2011). Pengembangan Profesi Guru: Dari Pra-Jabatan, Induksi ke Profesional Madani. Jakarta: Kencana Prenada Media Group.

Hasbullah. (2015). Kebijakan Pendidikan: Dalam Perspektif Teori, Aplikasi, 
dan Kondisi Objektif Pendidikan Indonesia. Jakarta: PT. Raja Grafindo Persada.

Hasibuan, L. (2010). Kurikulum dan Pemikiran Pendidikan. Jakarta: Gaung Persada.

Hendartyo, M. (2018, Juli 10). Tempo. Retrieved from Tempo: https://bisnis.tempo.co/read/11054 59/sri-mulyani-sindirtunjanganguru-besar-tapi-takberkualitas.

Hosnan. (2016). Etika Profesi Pendidik; Pembinaan dan Pemantapan Kinerja Guru, Kepala Sekolah Sera Pengawas Sekolah. Bogor: Ghalia Indonesia

Huda, T. (2017). Pengaruh Pelaksanaan Kebijakan KTSP dan Kompetensi Guru (Pai) terhadap Kinerja Proses Belajar Mengajar dalam Mewujudkan Perilaku Belajar Siswa Madrasah Aliyah Negeri Kabupaten Garut. Pedagogia, 15(1), 621-629.

Hughes. (2015). Psikologi Pembelajaran: Teori dan Terapan. Bandung: Nuansa Cendekia.

Idi, A. (2007). Pengembangan Kurikulum; Teori dan Praktik. Jogjakarta: Ar Ruz Media.

Ismail, M. I. (2010). Kinerja dan Kompetensi Guru dalam Pembelajaran. Lentera Pendidikan: Jurnal Ilmu Tarbiyah dan Keguruan, 13(1), 44-63.

Kunandar. (2007). Guru Profesional: Implementasi KTSP dan Sukses dalam Sertifikasi Guru. Jakarta: PT. Raja Grafindo Persada.
Mulyasa. (2012). Standar Kompetensi dan Sertifikasi Guru. Bandung: PT. Remaja Rosdakarya.

Mulyasa, E. (2015). Guru dalam Implementasi Kurikulum 2013. Bandung: PT. Remaja Rosdakarya

Murwati, H. (2013). Pengaruh Sertifikasi Profesi Guru terhadap Motivasi Kerja dan Kinerja Guru di SMK Negeri se-Surakarta. Jurnal Pendidikan Bisnis dan Ekonomi (BISE), 1(1), 1-10.

Nasution, S. (2001). Asas-Asas Kurikulum. Jakarta: Bumi Aksara.

Nurhayati, B. (2006). Faktor-Faktor yang Mempengaruhi Profesionalisme dan Kinerja Guru Biologi di SMAN Kota Makassar Sulawesi Selatan. Mimbar Pendidikan, 4(25), 64-70.

Sagala, S. (2013). Kemampuan Profesional Guru dan Tenaga Profesional. Bandung: Alfabeta.

Sanjaya, W. (2006). Strategi Pembelajaran Berorientasi Standar Proses Pendidikan. Jakarta: Kencana Prenada Media.

Sanjaya, W. (2013). Kurikulum dan Pembelajaran. Jakarta: Kencana Prenada Media Group.

Setiawan, D., \& Sitorus, J. (2017). Urgensi Tuntutan Profesionalisme dan Harapan Menjadi Guru Berkarakter (Studi Kasus: Sekolah Dasar dan Sekolah Menengah Pertama di Kabupaten Batubara). Cakrawala Pendidikan, (1), 122129.

Sindhunata. (2001). Pendidikan: Kegelisahan Sepanjang Zaman. Jogjakarta: Kanisius. 
Sudjana, N. (2013). Pembinaan dan Pengembangan Kurikulum di Sekolah. Bandung: Sinar Baru Algesindo.

Suparlan. (2005). Menjadi Guru Profesional. Jogjakarta: Hikayat Publishing.

Suryadi, A. (2014). Pendidikan Indonesia Menuju 2025, Outlook: Permasalahan, Tantangan dan Alterantif Kebijakan. Bandung: PT. Remaja Rosdakarya.

Suyono, H. (2015). Belajar dan Pembelajaran: Teori dan Konsep Dasar. Bandung: PT. Remaja Rosdakarya.

Usman, M. U. (2007). Menjadi Guru Profesional. Bandung: PT. Remaja Rosdakarya. 